\title{
MAKING MARKET INFORMATION SERVICES WORK BETTER FOR THE POOR IN UGANDA
}

\author{
Shaun Ferris, Catholic Relief Services (CRS) \\ Patrick Engoru, International Center for Tropical Agriculture (CIAT) \\ Elly Kaganzi, CHF International Rwanda
}

Presented at the Research Workshop on Collective Action and Market Access for Smallholders, 2-5 October 2006, Cali, Colombia

The CGIAR Systemwide Program on Collective Action and Property Rights (CAPRi) is an initiative of the 15 centers of the Consultative Group on International Agricultural Research (CGIAR). The initiative promotes comparative research on the role of property rights and collective action institutions in shaping the efficiency, sustainability, and equity of natural resource systems. CAPRi's Secretariat is hosted within the Environment and Production Technology Division (EPDT) of the International Food Policy Research Institute (IFPRI).

CAPRi Working Papers contain preliminary material and research results. They are circulated prior to a full peer review to stimulate discussion and critical comment. It is expected that most working papers will eventually be published in some other form and that their content may also be revised (http://dx.doi.org/10.2499/CAPRiWP77).

Copyright (C) May 2008. International Food Policy Research Institute. All rights reserved. Sections of this material may be reproduced for personal and not-for-profit use without the express written permission of but with acknowledgment to IFPRI. To reproduce the material contained herein for profit or commercial use requires express written permission. To obtain permission to reprint, contact the IFPRI Communications Division at ifpri-copyright@cgiar.org. 


\begin{abstract}
There is growing pressure for farmers in countries such as Uganda to accelerate their efforts to commercialize production in the face of increasing market competition from neighboring countries and across the world. To assist farmers, a new generation of low cost market information services is being developed that takes advantage of information and communication technologies such as FM radios, mobile phones, and internet-based communications systems, to enable farmers to monitor and adjust to dynamic market conditions in local, national, and export markets. Although there is much interest in market information from farmers, other market chain actors, and service providers, there is skepticism from funding agencies to support such services over the long term, due to past failures. This study therefore aims to evaluate how farmers access and use market information to improve their market decision making. It also evaluates whether there are any advantages of collective action in using market information to improve marketing decisions. This is considered an important point of analysis as virtually all extension plans in Uganda currently use farmer groups as key element of their learning and intervention strategies. Survey results found that all farmers interviewed were able to access market information through radio and mobile phones. In Uganda, up to 94 percent of farmers interviewed owned a radio and 25 percent of farmers owned mobile phones. Up to 52 percent of farmers indicated that receiving Market Information Services (MIS) had a positive impact on their business, and 39 percent stated that it had a lot of impact in terms of decision making and stabilizing incomes.
\end{abstract}

Keywords: Market Information Services, Group Marketing, Collective Action, FM Radio, Mobile Phone, SMS, Income. 


\section{ACKNOWLEDGEMENTS}

This work was sponsored by the Agricultural Sector Productivity Support Program in Uganda, funded by the Danish Embassy. 


\section{Table of Contents}

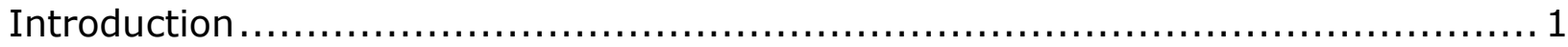

Method used to evaluate the National Market Information Service .................... 2

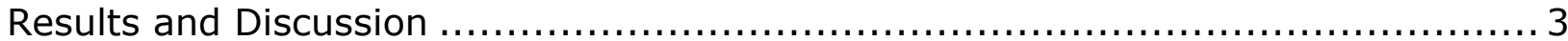

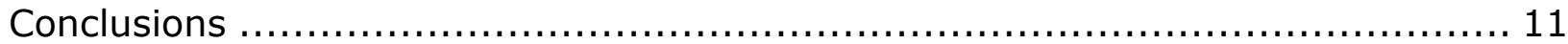

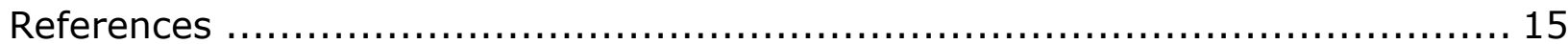




\section{MAKING MARKET INFORMATION SERVICES WORK BETTER FOR THE POOR IN UGANDA}

Shaun Ferris, ${ }^{1}$ Patrick Engoru, and Elly Kaganzi

\section{INTRODUCTION}

The provision of basic market information is a service that aims to increase the efficiency of agricultural markets and contribute towards overcoming issues of market failure based on asymmetric access to basic market information. In this paper, we define basic market information as commodity price data linked where possible with market demand conditions. In its simplest form, the provision of spot prices aims to assist farmers in being able to monitor market conditions and make better decisions on where to sell their produce and negotiate for improved prices rather than being compliant price takers. Similarly, rural and traveling traders, who have less access to market information than their urban counterparts, also use market information services to assist in their decision making and identification of spatial marketing opportunities.

According to Shepherd (1997), market information comes in two main formats: 1) public dissemination of prevailing market prices and conditions, and 2) provision of price trend analysis for specific commodities. Public provision of market information aims to reduce asymmetry of information in the marketplace. The rational is based on the premise that in all exchange relationships there are forces of market power at play, and the individual or group with most information tends to set prices. More equal access to market information encourages arbitrage $^{2}$ leading to greater uniformity in prices of a given commodity within a specific supply chain or country at a given time. The fundamental role of market information is therefore to encourage more efficient spatial and temporal arbitrage. The service also however, provides a channel for educating farmers about market trends, which assists in raising their level of engagement with the marketplace, a primary goal in those countries, where governments are seeking to increase the level of commercialization of the smallholder sector.

In most developing countries, market information is a public good service provided by a government department. These services generally involve the regular collection of commodity prices and supply conditions from major market centers by government staff. This information is sent to a centralized data processing center, typically housed in the Ministry of Agriculture or Trade, where it is collated before being disseminated back to a range of clients. The dissemination of prices and market news is achieved through various media options such as radio, newspapers, internet, email, mobile phone and notice boards to farmers, traders, government officials, policy makers, development agencies, and others, including consumers.

While spot information is most useful for direct sales negotiations and to keep abreast of market conditions, the collation of market information over the

\footnotetext{
${ }^{1}$ Corresponding author: sferris@crs.org.

${ }^{2}$ Arbitrage is the process of exchange of commodities with the objective of taking advantage of price differences that exceed transaction costs.
} 
longer term provides trend data that allows farmers and service providers to make decisions on which crops to grow and when to harvest crops based on seasonal price trends. Analysis of historical data has many other uses, for both public and private agents, and this type of data enables co-operative marketing agents to made more informed decisions on where to sell and how collective bulking, grading, and storage can be used to add vale to produce. Finance institutions use price data to monitor the long term health of the economy and in the short term to assess risks of lending to both large scale individual farmers and co-operative farming groups for speculative storage and trading options. Policy makers and researchers use both current and historical market information to review shifting market patterns and to assist in planning processes such as finding ways to foster market growth, planning for provision of appropriate marketing institutions and making decisions on when and where to invest in new marketing infrastructure.

Throughout Africa, market information is also routinely used to monitor food security conditions and for more accurate and timely provision of food relief. This area of food security management is increasingly relying on the use of market price data as a trigger indicator for food insecurity and also to identify areas for local procurement of food aid and subsequently to monitor the effects of procurement on commodity prices. Due to the range of potential users and uses of market information and the more prominent role of marketing in development interventions with farmer groups and food aid, there is increasing demand in accessing such data, but only if it is reliable, accurate, and readily accessible.

Despite these multiple benefits, there remains a continued level of skepticism from donors and Government agencies as to the need for long-term support to market information services (MIS). This lack of support is based on several factors, including poor past performance of government managed MIS, the long-term nature of the funding requirement, and lack of evidence to show the value of market information as a tool that can assist farmers and farmer groups to make better marketing decisions and increase their incomes.

This study aimed therefore evaluated the following questions: 1) How and how often farmers accessed market information? 2) What were the most effective delivery channels? 3) What are the costs and accuracy of the service? and 4) what were benefits to farmers and $(v)$ are gains amplified through combining access to market information and collective action through farmers groups in regard to income and market performance? ${ }^{3}$

\section{METHOD USED TO EVALUATE THE NATIONAL MARKET INFORMATION SERVICE}

To gain a better understanding of the reach, utility, and value of the national market information service in Uganda, a study was undertaken in 10 districts of Uganda to assess the views of a range of market chain actors in terms of their use

\footnotetext{
${ }^{3}$ Market Performance-a term used to describe the ability of farmers to increase their marketing skills, level of market engagement reflected by specific levels of organization, management acumen, increased produce sales prices, returns on investment, and the ability of farmers to re-invest in their enterprise.
} 
of the market information service, that has been operating from May 1999 to the time of the survey in July 2006. Target interviewees included individual farmers, farmers in groups, rural and urban traders, processors, radio managers, banks, local Government, and researchers. Data collection was purposefully biased towards farmers and rural traders, as these are considered the major beneficiaries of a market information service and the analysis is focused on farmer responses.

Figure 1. Districts surveyed highlighted in darker shaded areas

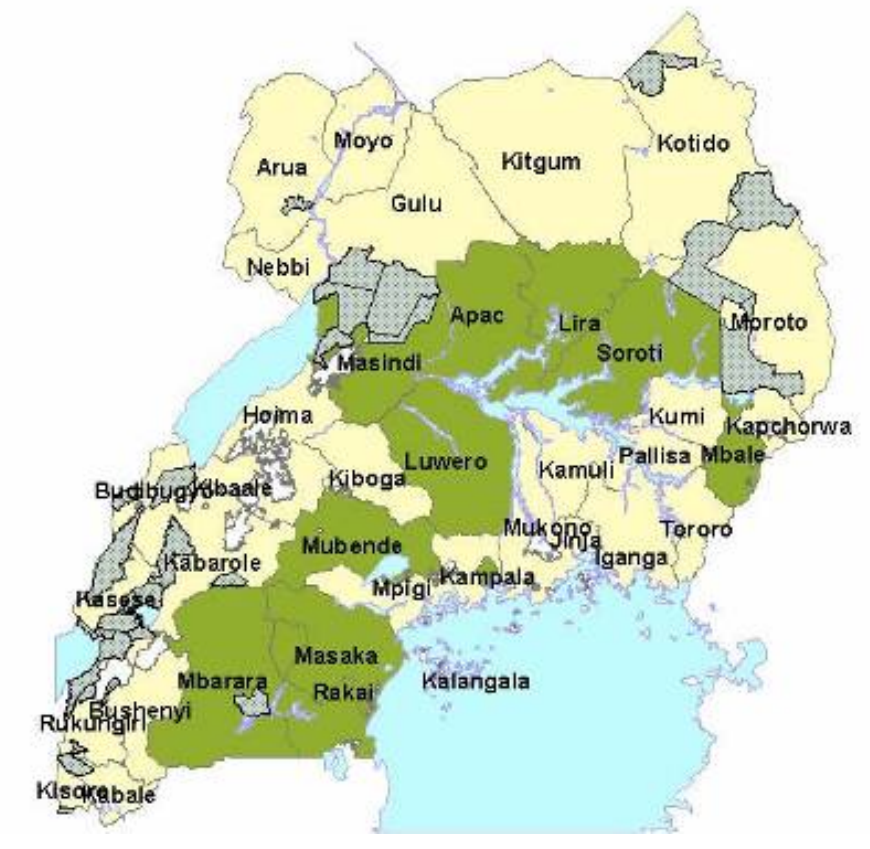

\section{RESULTS AND DISCUSSION}

Survey results showed the majority of farmers interviewed were smallholders with plot sizes ranging from 2.3 acres in the central and western parts of the country, up to 6.8 acres in less populated, northern areas. Figure 2 shows that annual incomes ranged from US $\$ 97$ in the northern districts, which have been affected by chronic insecurity up to US\$756 in the western districts of the country. 
Figure 2. Average farm income based on season and region

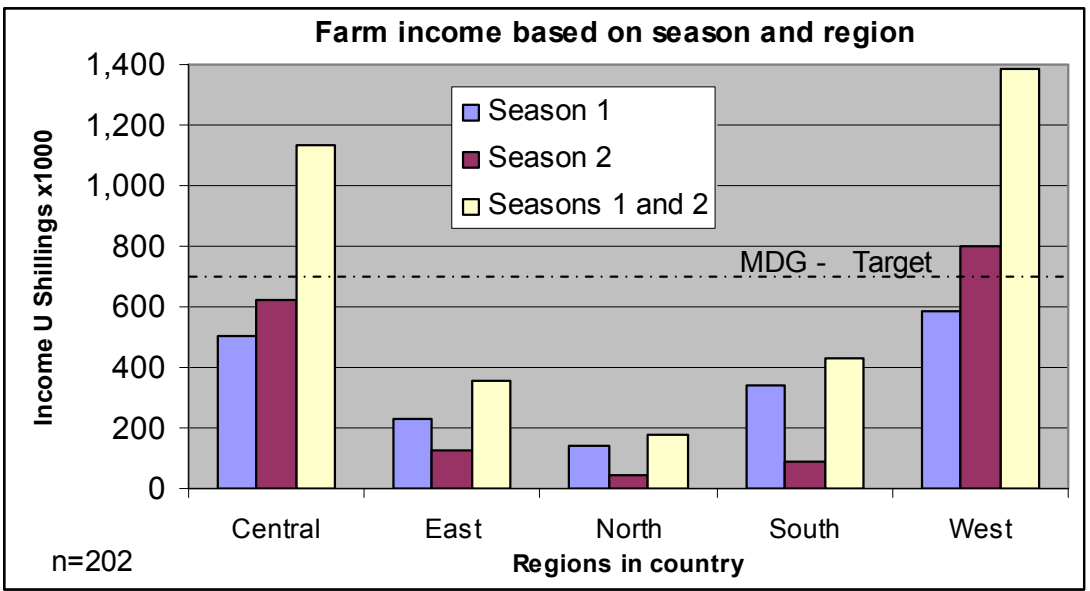

US\$1=1850 Uganda shillings

The diagnostic data indicated that four of the top income-earning crops were non-traditional export products, as shown in Figure 3. This shift away from the traditional cash crops, such as coffee, tea, sugar, and cotton, indicates the increasing commercialization of food crops, especially maize, beans, and groundnuts, which have become important in both domestic and regional markets. The success of these crops is much to do with long-term support from development projects in non-traditional crop production, through interventions such as USAID's IDEA project, ${ }^{4}$ combined with increased levels of local procurement for food aid by the World Food Programme (WFP).

Figure 3. Leading income generating crops sold by farmers

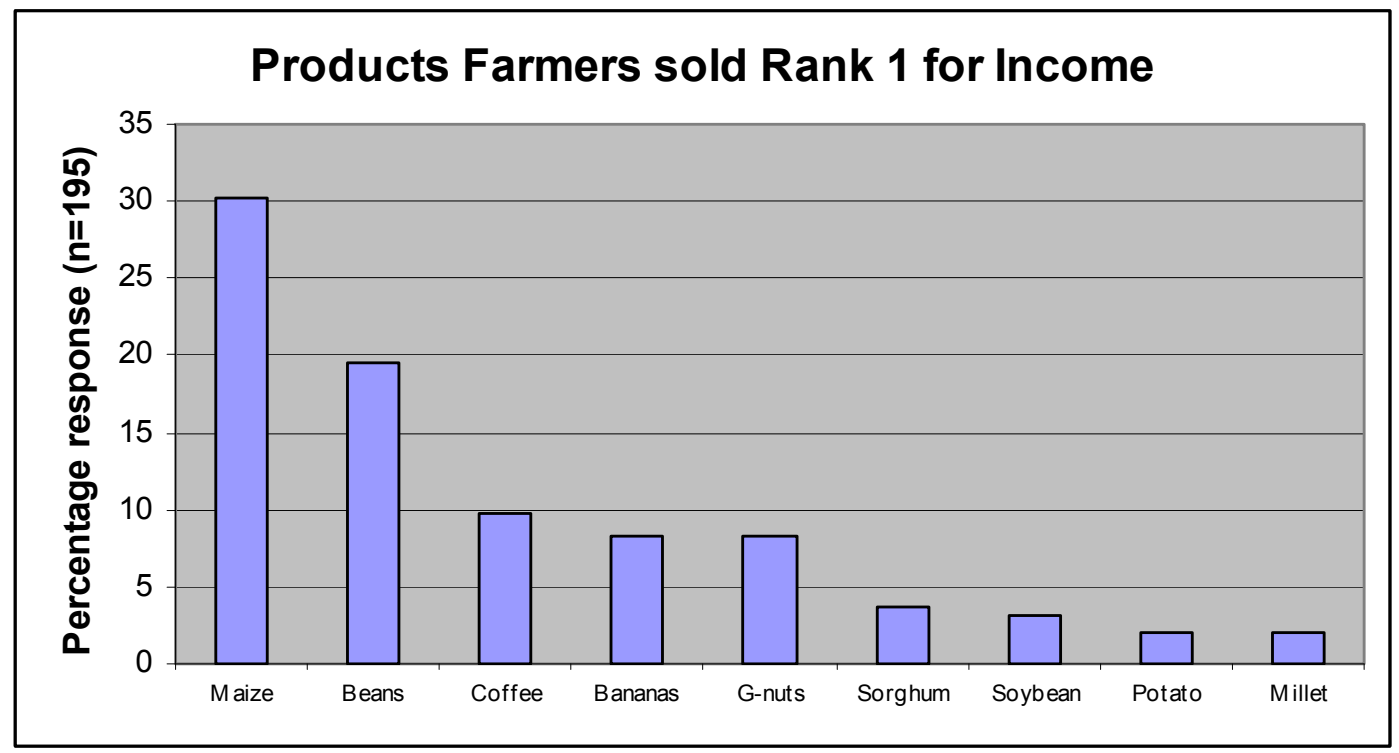

${ }^{4}$ IDEA - Investment in Developing Export Agriculture - Agricultural Development Centre 


\section{Marketing structures and strategies}

As part of the drive to commercialize smallholder farmers in Uganda, considerable efforts have been placed on formalizing market linkages and improving the marketing competence of farmers and farmer organizations. This was done in an attempt to build better business relations between the millions of atomized smallholder producers and larger buyers. One of the most widely adopted strategies for strengthening the commercial capacity of farmers has been to organize farmers into collective marketing groups. In Uganda, 65 percent of farmers were members of at least one group, and two thirds of these groups stated their main aim was to improve their production and marketing practices (see Figure 4).

Figure 4. Farmers enrolled in groups and purposes of the group

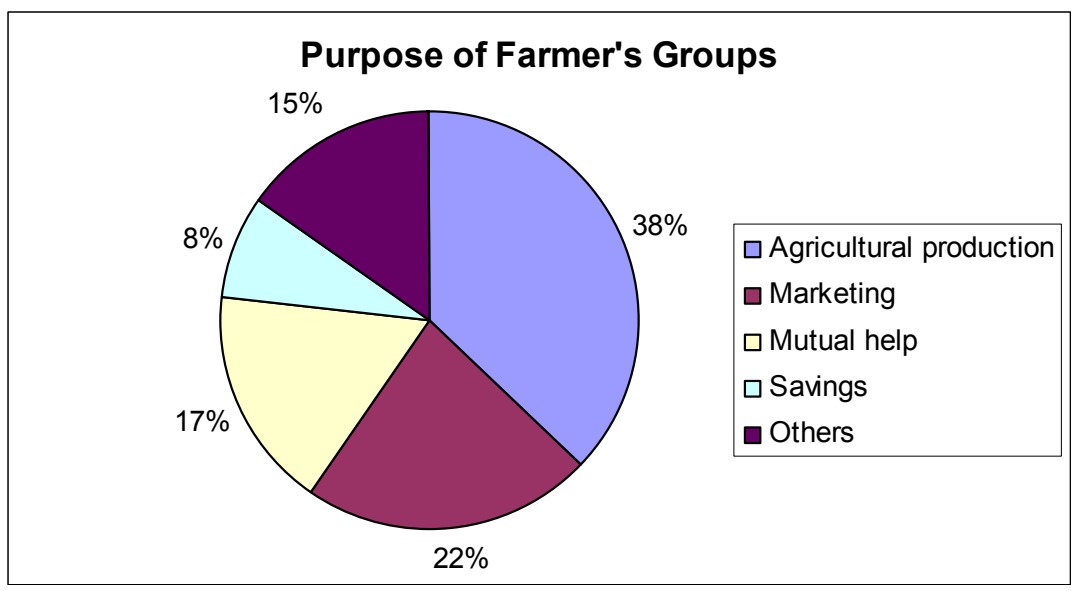

\section{Developing new market information models}

To support the commercial aspirations of farmer groups, the International Centre for Tropical Agriculture (CIAT) and partners, including the International Institute of Tropical Agriculture (IITA), the Centre for Technical Co-operation for Agriculture in ACP countries (CTA), USAID, and FEWSNET developed a range of low-cost market information services at the local-district level, national, and regional levels. The aim of these services was to provide farmers, rural traders, and processors with an independent, reliable and up to date guide to prevailing market prices and market conditions. This was done to support their sales negotiations and to strengthen their ability to make more informed market decisions.

This study focused on the effectiveness of the National Marketing Information Service, which was re-launched in 1999 following the collapse of the government service. The service focused on 25 products and 20 markets with information being disseminated back to farmers and rural traders on a weekly basis through rural FM radios, mobile phones, email, and the internet.

\section{Delivering market information to farmers in Uganda}

One of the most problematic areas for Government led MIS's was their inability to disseminate data to the farmers on a regular basis, (Robbins 1999). In the 1990s, Uganda was reliant on one government radio for broadcasting news to the nation, which was free to government ministries. However, when the national station 
became fee-based, as part of structural adjustment processes, broadcasting of market news ceased. The liberalization of the airwaves in 1993 also crowded out the State radio as more than 120 local FM stations were established across the country (Tanburn and Kamuhanda, 2005). These rural radios, often with a footprint of $10-50 \mathrm{~km}$, were able to broadcast programs in the local language and were thus extremely popular with local communities. The market information service established in 1999 capitalized on this new rural FM network and the survey revealed that 13 radio stations regularly broadcast market information. While all of the broadcasts were publicly funded in 1999, at the time of the survey in 2006 nearly half of the stations were broadcasting the program without public funds, as shown in Figure 5.

\section{Figure 5. MIS radio coverage in Uganda, 2006}
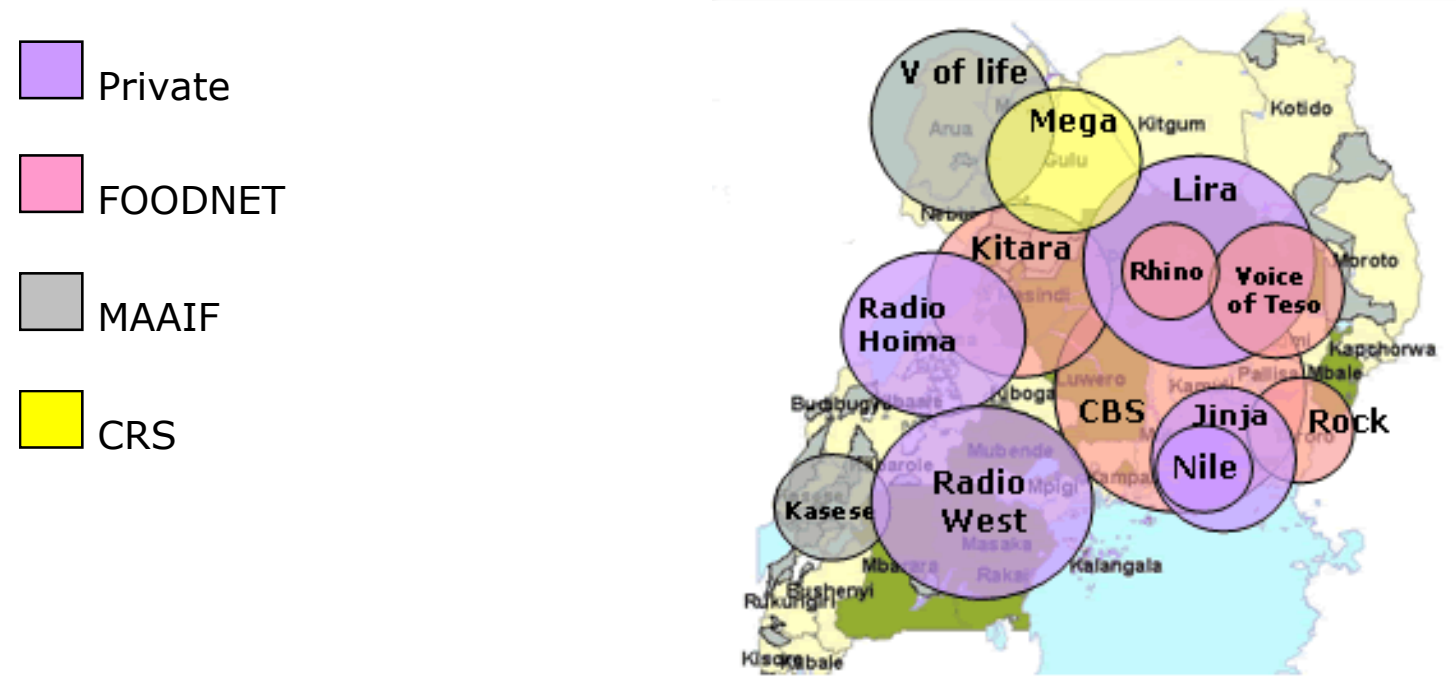

The rise of rural radio met with great success from the local communities and we found that up to 94 percent of farmers owned a radio. This is a remarkably high number and indicates the demand for such services and the power of rural radio as a vehicle for communication to the rural community. Farmers confirmed that within educational types of information, they were most interested in farming and market news. Not surprisingly, the main and preferred source of accessing market information for 68 percent of farmers was through listening to the regular radio market information broadcasts as shown in Figure 6.

In 1995, the Government liberalized the phone network, which led to the establishment of three mobile phone service providers setting up a competitive nationwide network. Once again this policy shift revolutionized ideas on how to communicate with the rural community and 24 percent of farmers in this survey owned a mobile phone. An even more impressive 86 percent of farmers claimed access to a phone. In contrast, the penetration of computers to farmers was found to be virtually zero; no farmers owned a computer and no farmers were using cybercafés to access market information.

These findings clearly support the strategy used by the MIS team in Uganda to focus the dissemination of information to farmers via radio and mobile phone. The coverage for both communication systems is extremely high for a developing 
country and this shows the potential for using these technologies as tools for communicating and providing services to the farming community. Mobile phones are particularly interesting as this method offers two way communications which farmers can use to follow up on market opportunities and in the future to transact market deals. For traders we found that the most useful service for small rural and traveling traders was the radio, whereas for the larger urban traders, they preferred to receive the market information through email and the internet.

Figure 6. Farmers' main sources of market information

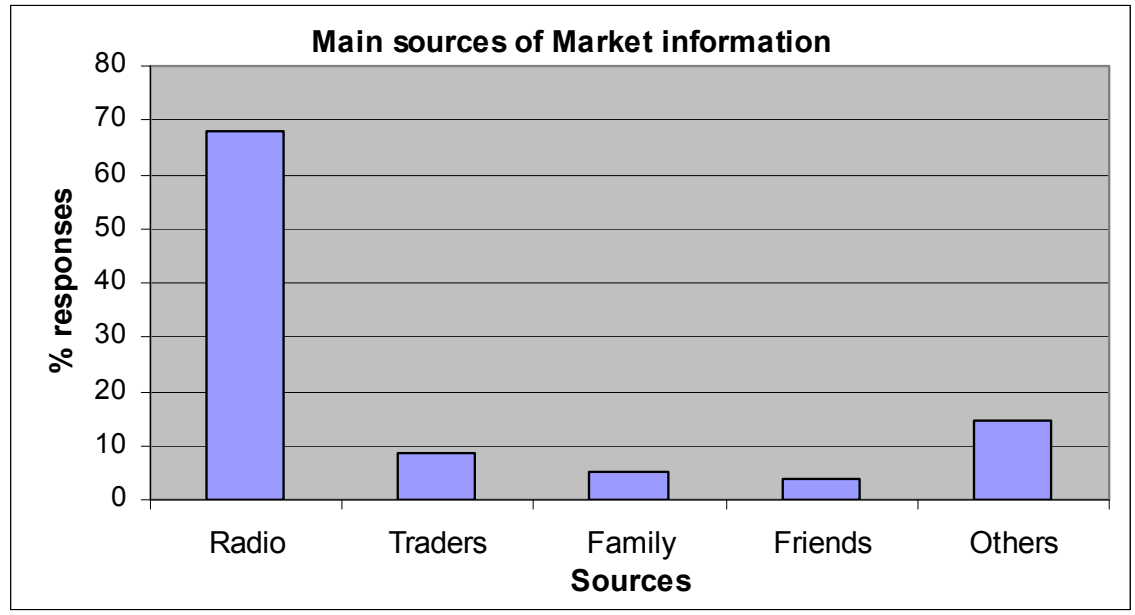

\section{Costs of the market information service}

While the previous section confirmed the method of disseminating market information to specific user groups, a key question for the donor group was whether market information was a cost effective means of supporting the marketing decisions of farmer groups. A simple analysis of the national market information service based on start up and recurrent costs found that costs averaged across a three-year period, with an estimated coverage to 4,000,000 households per week, was approximately US\$.018 per household per year. This is a relatively low-cost service compared with US\$75 required to support extension workers physically visiting households. This comparison highlights the efficiency of using ITC technologies when clear messages are available.

In an attempt to evaluate the usefulness, accuracy, and reliability of the information disseminated through the national MIS service, farmers were asked to score the quality of the service and to indicate how the information was used in trading. Responses showed that 93 percent of farmers found the MIS to be in the "very" to "fairly useful" range, which is a strong endorsement of the service in terms of getting information to the client group and them being able to understand and use this information. 
Figure 7. Farmers rating of the current agricultural market information in Uganda

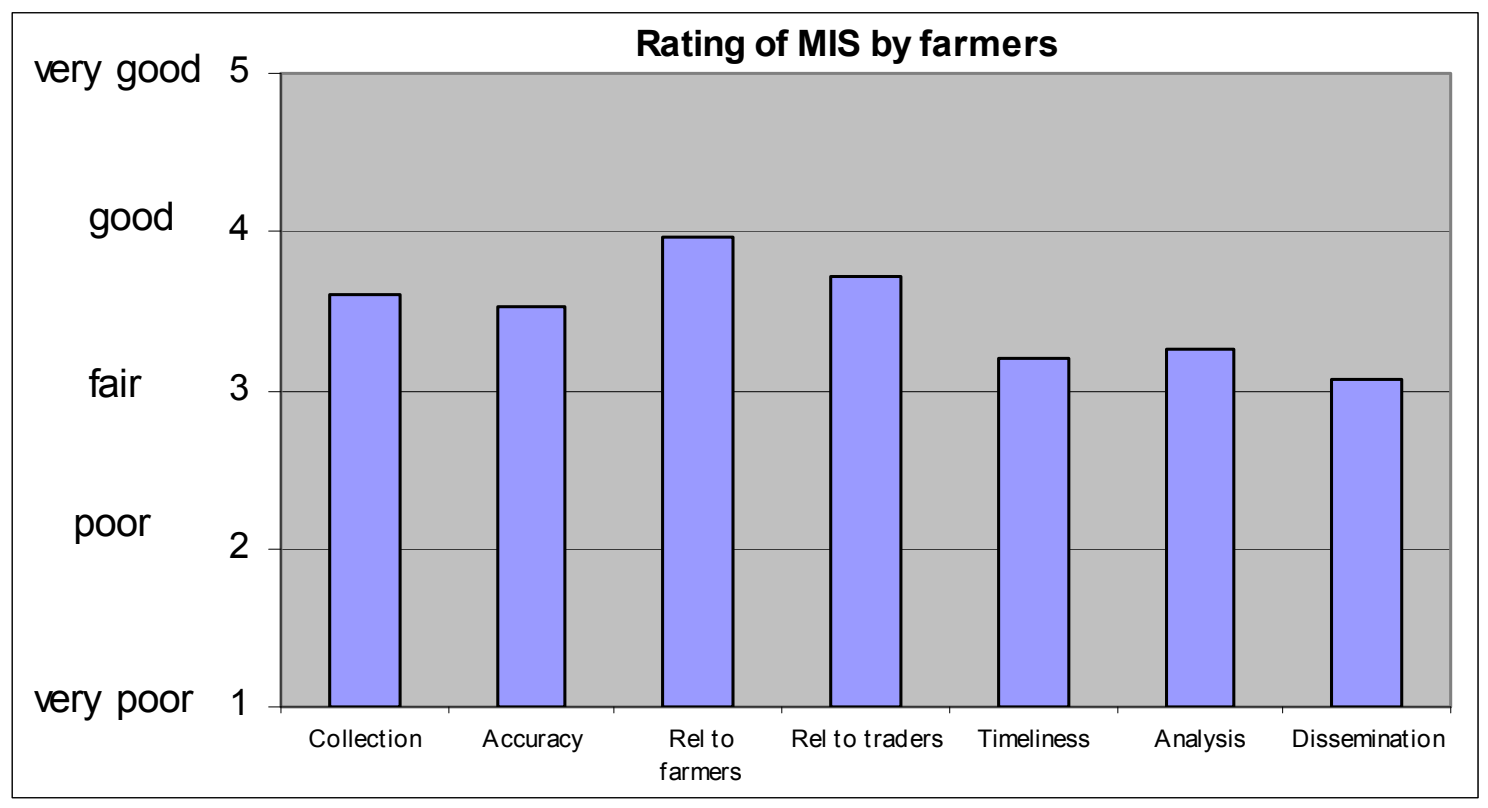

In terms of how the market information was used, results presented in Table 1 showed that market information was used by both individual farmers and farmer groups to make a series of decisions on their production and marketing decisions. Up to 90 percent of farmers in groups regularly used the information to learn about market prices prior to selling produce and make decisions on what types of produce to grow, where to sell, and when to sell in the season. Based on this analysis, there is clearly a strong role being played by MIS in strengthening greater business acumen for farmer groups and also their service providers who can use such information to advise farmers on new market options.

Table 1. Relevance and usefulness of market information

\begin{tabular}{|l|l|l|}
\hline & Farmers & Farmer Groups \\
\hline Learning about produce sales price & $76 \%$ & $89 \%$ \\
\hline In deciding what to plant & $63 \%$ & $80 \%$ \\
\hline In deciding which market to sell produce & $73 \%$ & $83 \%$ \\
\hline In deciding when to sell & $59 \%$ & $46 \%$ \\
\hline In negotiating with traders for better prices & $40 \%$ & $39 \%$ \\
\hline
\end{tabular}

Source: NAADS MIS review 2005

\section{Financial benefits of market information}

The more difficult question to answer is the level of financial benefit accruing to farmers as a result of receiving and using market information. Gaining clarity on this issue is problematic because of confounding factors involved in any one transaction, caused by price volatility, changes in market access, produce volumes, and comparisons of the quality of produce at the time of sale. Given these limitations individual farmers and farmers in groups, were asked to describe how 
they used market information in previous negotiations and how this affected sales prices.

This analysis found that 42 percent of the farmers indicated that even when they regularly listened to the market news services, they were unable to influence sales prices and increase their income above prevailing prices by using market information. The other farmers described a series of situations where they had used market information to make decisions to increase their incomes. A key finding in this analysis was that up to 56 percent of farmers working in groups compared to 30 percent of farmers trading as individuals were able to make gains through the use of market information. Table 2 shows that, on average, gains were also higher for farmers in groups compared to farmers selling as individuals.

Table 2. Price gains by individual and farmers in groups

\begin{tabular}{|l|l|l|}
\hline & Farmers & Farmers in Groups \\
\hline Percentage number of farmers who gained & $30 \%$ & $56 \%$ \\
\hline $\begin{array}{l}\text { Average \% increase gain above prevailing } \\
\text { prices across all farmers in category }\end{array}$ & $16 \%$ & $24 \%$ \\
\hline
\end{tabular}

Within specific crops the price gains indicated by farmers who were able to use MIS successfully showed there were a number of strategies where MIS was used in combination with other strategies to improve income, as shown in Table 3.

Table 3. Price gains within product types

\begin{tabular}{|l|l|l|l|}
\hline & MIS + group & $\begin{array}{l}\text { MIS + group }+ \\
\text { location }\end{array}$ & $\begin{array}{l}\text { MIS + group }+ \\
\text { storage }\end{array}$ \\
\hline Bananas & $45 \%$ & $60 \%$ & \\
\hline Beans & $31 \%$ & $63 \%$ & $158 \%$ \\
\hline Coffee & $32 \%$ & $71 \%$ & $156 \%$ \\
\hline Maize & $28 \%$ & $49 \%$ & $77 \%$ \\
\hline Mean & $\mathbf{3 4 . 0}$ & $\mathbf{6 0 . 8}$ & $\mathbf{1 3 0 . 2}$ \\
\hline
\end{tabular}

To give greater insight into the types of strategies where MIS was used successfully, the information in Table 4 provides a range of cases where MIS was used by farmer selling beans. The decisions and strategies outlined resulted in a range of losses and gains relative to prevailing prices from -60 percent to +250 percent beans. Highest gains were made through combinations of using MIS and collective storage and groups selling their produce into new locations for sales. It should be noted, however, that these figures are for increases in gross margins and do not take into accounts the additional marketing and transactional costs that may have been incurred through alternatives sales methods. 


\section{Table 4. Illustrative descriptions of marketing strategies for beans in Uganda}

\begin{tabular}{|l|l|l|}
\hline $\begin{array}{l}\text { Crop } \\
\text { Type }\end{array}$ & Description of Transaction & $\begin{array}{l}\text { \% change } \\
\text { in price* }\end{array}$ \\
\hline Beans & $\begin{array}{l}\text { The group was offered a low price 300shs/kg but group } \\
\text { secured a buyer at 500shs/kg }\end{array}$ & 67 \\
\hline Beans & $\begin{array}{l}\text { Members in our group sold our beans at } 400 / \mathrm{kg} \text { but other } \\
\text { farmers in the village were selling at 300/kg. }\end{array}$ & 33 \\
\hline Beans & $\begin{array}{l}\text { Our group leader enabled us to sell our beans in a group } \\
\text { and we got shs 500/kg people who were not in a group } \\
\text { received shs 400/kg }\end{array}$ & 25 \\
\hline Beans & $\begin{array}{l}\text { People in the village sold beans at 350-400shs } / \mathrm{kg}, \text { but the } \\
\text { group found a buyer at 500shs } / \mathrm{kg}\end{array}$ & 25 \\
\hline Beans & $\begin{array}{l}\text { Bean prices were 7000shs per debe but market information } \\
\text { was 8000shs, so I sold my stock quantity at high price }\end{array}$ & 12.5 \\
\hline Beans & $\begin{array}{l}\text { A local producer bought my beans at } 500 / \mathrm{kg} \text { at a time } \\
\text { when majority farmers were selling at shs 400/kg. This was } \\
\text { because I told him that I had knowledge of the price in } \\
\text { Masaka town. }\end{array}$ & 25 \\
\hline Beans & $\begin{array}{l}\text { Buyers were offering } 400 \text { shs } / \mathrm{kgs} \text { for beans in our village } \\
\text { but when radios announced a price of } 500 \text { shs } / \mathrm{kg} \text { the group } \\
\text { negotiated at that price }\end{array}$ & 25 \\
\hline
\end{tabular}

*All prices rounded to nearest decimals

Similar gains were shown by maize farmers, with sales gains ranging from 0150 percent above prevailing market prices. These levels of gain may appear unexpectedly high, due to the use of percentage increases and therefore the following example has been reconstructed to provide information on the potential benefits to farm gate incomes for a typical smallholder maize farmer in Uganda. If we assume that a farmer sells $1 \mathrm{mt}$ of maize for 200,000 Uganda Shillings, a price gain of 20 percent would provide an additional income of Ugs 40,000 (US\$21.62). Given that most farmers have $0.5-1$ ha of land, with a production capacity of 2-3 $\mathrm{mt} / \mathrm{ha}$, a successfully negotiated sale, that captures current prices, may add an additional US\$40-\$80 to an annual income, which would have significant social benefits to the farm family, particularly those living in the poorer and northern parts of the country. In most cases, farmers working in groups were able to enjoy such gains more frequently than farmers selling as individuals.

The analysis also suggests that the likelihood of improving market performance increases when farmers combine the use of market information with collective marketing, as the group provides a stronger platform to negotiate for better prices as buying a bulked product is more attractive to buyers than buying in small lots from individuals. These are encouraging signs for the development and extension agents in Uganda, who are placing considerable effort on the process of establishing farmers groups, and strengthening their capacity to produce a high quality product for collective sales to a known buyer. 
Farmers also observed that since they started receiving market information, they are now paying more attention to more sophisticated buying conditions such as grain moisture content and kernel quality. Moisture content is one of the most important criteria used by formal buyers, as this affects the conditioning they need to invest in the grain to bring it up to export quality. The more commercial farmers, typically in farmer associations are seeking to harvest at the correct time, dry their crops more effectively and sort and clean the grains in an attempt to access premium prices. These are all encouraging signs for the development and extension agents in Uganda, who are placing considerable effort on the process of establishing farmers groups, and strengthening their capacity to produce a high quality field product that retains a high quality through basic but important post-harvest handling methods. It is unlikely that these types of activities will be done, however, unless there is a clear market signal which provides farmers with an incentive and reassurance to make the investments required to sell a premium quality product. Market information is a low-cost means of supporting this process, and if the more commercial farmers have confidence in this type of information, it will play a useful role in the transition from sales of ungraded, low quality produce, towards a more standardized product that will receive premium prices and be attractive for buyers not only in Uganda but in the region.

\section{CONCLUSIONS}

In contrast to most countries in Eastern Africa, research teams in Uganda have invested considerable efforts since 1999 in developing low-cost market information services, based on studies by Kleih (Kleih et al., 1999) and Odwongo (2000), which outlined the value of market information in assisting smallholder farmers to become more commercially oriented.

Findings revealed that more than 90 percent of farmers in Uganda own radios and regularly listen to the weekly market information news and that the preferred method of receiving this data was through local FM radio. Uganda has eight major language groups and therefore providing MIS data through a number of FM radios has played an important role in promoting the MIS to the wide range of language groups. At the time of this study 25 percent of farmers owned a mobile phone, and virtually 100 percent indicated they had access to mobile phones. However, few farmers are using this media for monitoring market prices. Details from the survey suggest that most farmers are currently not aware that price data is available on mobile phones and are unaccustomed to using their phones to access business information. In contrast rural and traveling traders are increasingly using market information through mobile phone short message service (SMS) services in Uganda to gain a better understanding of spatial trading opportunities.

Based on these findings, it would suggest that service providers should continue to focus on FM radio as the most appropriate medium for providing market information to farmers. SMS linkage should be promoted for use by traders and in the future and further training through the extension services is required to make SMS a more effective tool for farmers. The longer term preference for SMS phone systems is that they are lower cost than radio, can be updated and accessed more regularly. SMS also offers the provider a simpler means of revenue capture for provision of such services to the users. Training programs in SMS usage may be of 
particular benefit at the farmer association level, as mobile phone also offers the opportunity for two way communications, which is vital to building effective and long-term business relations and for negotiating sales at distance.

The evidence from the survey showed that once farmers received market information, they were able to understand and use this data to monitor market changes and to apply this information to a range of marketing decisions. These included making decisions what crops to plant, selection of market location, when to sell in the season, making improvements on quality, speculative storage, and for improving the negotiating capacity of farmers to gain better sales prices with traders. This is a significant number of behavioral changes based on the provision of a simple but trusted market signal.

While it is encouraging to find that the majority of farmers receiving regular price data were using this in a number of ways to improve their market performance, 42 percent of farmers were unable to use MIS effectively. These results present a challenge for extension agencies and to MIS providers. For those clients using price data successfully, there is demand for additional information which links price with marketing conditions, such sales volume and quality, to promote grading and premium prices. For those farmers who are unable to use price data, they may require additional training or access to simple instructions on how to understand and use MIS, as provided by Shepherd (1997), and also how to organize themselves into groups that can take better advantage of collective marketing approaches.

The findings from the report clearly indicate that farmers in groups benefit from price based decision making more rapidly and more often than individual farmers, which supports the general consensus that learning and applying new skills is achieved more rapidly through collective approaches (Gallagher, 2003). The power of collective action was evident when farmers in groups were able to bulk their produce and negotiate more effectively with buyers. This advantage was increased considerably when farmer groups bulked their goods and sold into new markets and highest gains were observed when farmers stored goods for speculative trading based on monitoring seasonal price movements.

The benefits of storage, particularly in growth markets such as maize in the past two to three years in Uganda, indicates that attention should be given to combined strategies for using MIS, such as MIS plus the use of near farm storage in future development projects in Uganda. At present most farmers store for short periods of time, in their houses, or in old cotton stores that were built in the 1950s and 1960s. The conditions and management of most stores is poor and farmers tend to sell early in the harvest season to avoid losses caused by rapid deterioration. Future projects should therefore place greater emphasis on postharvest handling, such that farmer groups or associations can bulk, clean, grade, and store their produce to improve storage prospects. This is a considerable amount of upgrading and therefore, pilot testing at the association levels, will need to start this process.

Another key impediment to farmers, groups and associations being unable to take advantage of storage options is the lack of rural and term finances to support the linkage between production and storage. To address this situation, more sophisticated approaches, such as warehouse receipts schemes, are being tested to offer farmers the opportunity to raise cash using stored produce. However, for 
these more sophisticated approaches to be successful, both lenders and borrowers will require a rapid means of price and reliable means of discovery and a sound understanding of market price trends, to judge the merits and profitability of storage options. Greater use of such approaches will also require more specialization within farmer groups or associations, such that markets are rigorously monitored, and that group members can provide basic financial advice on long term market trends and advise others of the potential gains and losses associated with speculative options. External agencies, service providers, and NGOs will also require skills in these areas if they are to provide sound advice on these matters to client groups. Their ability to do this now is limited to a few service providers which have recruited staff with marketing skills.

For farmers who are currently using market information effectively, it is noteworthy that the changes in behavior observed within the farming community have been achieved with virtually no face-to-face training with farmers. Given that that costs for distance learning methods are considerably cheaper than direct training, the example of market information being widely used by farmers in Uganda suggests two things: first, that more emphasis should be placed on providing extension messages through radio and mobile phones media, particularly simple messages on current farming issues, so that they are more widely adopted by farmers; secondly, that if extension agents want more farmers to apply value adding methods, they should place more attention on promoting the ability of farmer groups to understand market signals to build demand for new farming technologies, rather than place all of their efforts on demonstrating production gains.

Based on these findings it would appear that the previous investments in MIS have been effective and the results suggest that market information does play an effective role in orienting farmers towards market opportunities. The application of MIS can be done by individual farmers but more effective gains were made by farmers in groups. The most effective use of MIS was apparent when used in combination with other marketing strategies such as bulking, storage and quality upgrading.

For those farmers who are using market information regularly, the results suggest that more attention should be given to quality parameters in market information and if this is done, the link between price and quality would strengthen the process of developing a more competitive marketing environment. In the future, therefore, a more integrated package of radio based training and information provision in combination with farmer groups and associations could be an effective strategy for linking farmers to more remunerative markets. The use of radio based training to support market information use and collective marketing was tested by IITA and NRI in the Lira district of Uganda in 2001, through a series of radio programs entitled "Market to Market", NRI, 2001. The results from this study indicated that farmers were highly motivated to test new approaches such as collective marketing and market price monitoring when these approaches and services were supported with radio based training.

Of most interest to long term funding agencies and government was the consistent evidence of increased marketing competence and improved market performance based on the combination of collective marketing that was informed by access to market prices and market news. Many individual farmers made 
consistent gains and therefore, not being is a group does not preclude farmers from being more competitive market actors. However, the numbers of farmers that gained was higher in groups and the market gains, though modest, were being made by poor farmers. Hence, market information is able to penetrate areas beyond traditional extension services and make direct impact on the lives of the poor. 


\section{REFERENCES}

Benin, S., E. Nkonya, G. Okecho, J. Pender, S. Mugarura, and E. Kato. 2005. Quantifying the impact of the National Agricultural Advisory Services in the Uganda Rural Livelihoods. NAADS Household Survey, Study supported by World Bank via NAADS. pp 45

Chemonics International. 2004. APEP First Annual Report. USAID.

Ferris, R.S.B., P. Engoru, M. Wood, and E. Kaganzi. 2006. Evaluation of the Market Information Services in Uganda and Recommendations for the Next Five Years. Contract for PMA / ASPS. Danish Embassy, Kampala, Uganda.

Gallagher, K. 2003. Adapted from Fundamental elements of a Farmer Field School. LEISA 19:1, March 2003. pp. 5-6

IDEA Project Final Review. Chemonics International, Inc. Printed in Uganda, Kampala.

Kleih, U., W. Odwongo, and C. Ndyashangaki. 1999. Community Access to Marketing Opportunities: Options for Remote Areas. NRI report No 2442, Project A0769. Uganda Case Study:60.

Mc Guigan, C., F. Zake, D. Luswata-Kibanda, P. Nyabuntu, J. Ssemwanga. 2005. Developing and promoting trading principles for the Ugandan Agro-business sector. BSMD project document, Kampala, Uganda:21.

Odwongo, W. O. 2000 The Role of Market Information within the Plan for the Modernisation of Agriculture in Uganda. In Stakeholders Meetings for Strengthening the Market Information Service in Uganda. IITA Monograph No 28:75. Ibadan, Nigeria.

Shepherd, A.W. 1997. Market information services: Theory and Practice. Food and Agriculture Organiaation of the United Nations, Rome. pp58

Tanburn, J. and R. Kamuhanda. 2005. Making service markets work for the poor: The experience of Uganda. DFID / ILO supported consultancy Report for Business Services Market Development Project, Uganda. Kampala. pp 76.

Robbins, P. 1999. Review of market information systems in Botswana, Ethiopia, Ghana and Zimbabwe. A technical report commissioned by the Technical Centre for Agricultural Rural Cooperation (CTA). pp 60.

Van Bussel, P. 2005. Business Services Market Development Experiences and Lessons. BSMD Synthesis Paper. Kampala, Uganda. p26. 


\section{LIST OF CAPRI WORKING PAPERS}

01 Property Rights, Collective Action and Technologies for Natural Resource Management: A Conceptual Framework, by Anna Knox, Ruth Meinzen-Dick, and Peter Hazell, October 1998.

02 Assessing the Relationships between Property Rights and Technology Adoption in Smallholder Agriculture: A Review of Issues and Empirical Methods, by Frank Place and Brent Swallow, April 2000.

03 Impact of Land Tenure and Socioeconomic Factors on Mountain Terrace Maintenance in Yemen, by A. Aw-Hassan, M. Alsanabani and A. Bamatraf, July 2000.

04 Land Tenurial Systems and the Adoption of a Mucuna Planted Fallow in the Derived Savannas of West Africa, by Victor M. Manyong and Victorin A. Houndékon, July 2000.

05 Collective Action in Space: Assessing How Collective Action Varies Across an African Landscape, by Brent M. Swallow, Justine Wangila, Woudyalew Mulatu, Onyango Okello, and Nancy McCarthy, July 2000.

06 Land Tenure and the Adoption of Agricultural Technology in Haiti, by Glenn R. Smucker, T. Anderson White, and Michael Bannister, October 2000.

07 Collective Action in Ant Control, by Helle Munk Ravnborg, Ana Milena de la Cruz, María Del Pilar Guerrero, and Olaf Westermann, October 2000.

08 CAPRi Technical Workshop on Watershed Management Institutions: A Summary Paper, by Anna Knox and Subodh Gupta, October 2000.

09 The Role of Tenure in the Management of Trees at the Community Level: Theoretical and Empirical Analyses from Uganda and Malawi, by Frank Place and Keijiro Otsuka November 2000.

10 Collective Action and the Intensification of Cattle-Feeding Techniques: A Village Case Study in Kenya's Coast Province, by Kimberly Swallow, November 2000.

11 Collective Action, Property Rights, and Devolution of Natural Resource Management: Exchange of Knowledge and Implications for Policy, by Anna Knox and Ruth Meinzen-Dick, January 2001.

12 Land Dispute Resolution in Mozambique: Evidence and Institutions of Agroforestry Technology Adoption, by John Unruh, January 2001.

13 Between Market Failure, Policy Failure, and .Community Failure.: Property Rights, CropLivestock Conflicts and the Adoption of Sustainable Land Use Practices in the Dry Area of Sri Lanka, by Regina Birner and Hasantha Gunaweera, March 2001.

14 Land Inheritance and Schooling in Matrilineal Societies: Evidence from Sumatra, by Agnes Quisumbing and Keijuro Otsuka, May 2001.

15 Tribes, State, and Technology Adoption in Arid Land Management, Syria, by Rae, J, Arab, G., Nordblom, T., Jani, K., and Gintzburger, G., June 2001.

16 The Effects of Scales, Flows, and Filters on Property Rights and Collective Action in Watershed Management, by Brent M. Swallow, Dennis P. Garrity, and Meine van Noordwijk, July 2001.

17 Evaluating Watershed Management Projects, by John Kerr and Kimberly Chung, August 2001.

18 Rethinking Rehabilitation: Socio-Ecology of Tanks and Water Harvesting in Rajasthan, NorthWest India, by Tushaar Shah and K.V.Raju, September 2001.

19 User Participation in Watershed Management and Research, by Nancy Johnson, Helle Munk Ravnborg, Olaf Westermann, and Kirsten Probst, September 2001.

20 Collective Action for Water Harvesting Irrigation in the Lerman-Chapala Basin, Mexico, by Christopher A. Scott and Paul Silva-Ochoa, October 2001.

21 Land Redistribution, Tenure Insecurity, and Intensity of Production: A Study of Farm Households in Southern Ethiopia, by Stein Holden and Hailu Yohannes, October 2001. 
22 Legal Pluralism and Dynamic Property Rights, by Ruth Meinzen-Dick and Rajendra Pradhan, January 2002.

23 International Conference on Policy and Institutional Options for the Management of Rangelands in Dry Areas, by Tidiane Ngaido, Nancy McCarthy, and Monica Di Gregorio, January 2002.

24 Climatic Variablity and Cooperation in Rangeland Management: A Case Study from Niger, by Nancy McCarthy and Jean-Paul Vanderlinden, September 2002.

25 Assessing the Factors Underlying the Differences in Group Performance: Methodological Issues and Empirical Findings from the Highlands of Central Kenya, by Frank Place, Gatarwa Kariuki, Justine Wangila, Patti Kristjanson, Adolf Makauki, and Jessica Ndubi, November 2002.

26 The Importance of Social Capital in Colombian Rural Agro-Enterprises, by Nancy Johnson, Ruth Suarez, and Mark Lundy, November 2002.

27 Cooperation, Collective Action, and Natural Resources Management in Burkina Faso: A Methodological Note, by Nancy McCarthy, Céline Dutilly-Diané, and Boureima Drabo, December 2002.

28 Understanding, Measuring, and Utilizing Social Capital: Clarifying Concepts and Presenting a Field Application from India, by Anirudh Krishna, January 2003.

29 In Pursuit Of Comparable Concepts and Data, about Collective Action, by Amy Poteete and Elinor Ostrom, March 2003.

30 Methods of Consensus Building for Community Based Fisheries Management in Bangladesh and the Mekong Delta, by Parvin Sultana and Paul Thompson, May 2003.

31 Formal and Informal Systems in Support of Farmer Management of Agrobiodiversity: Some Policy Challenges to Consolidate Lessons Learned, by Marie Byström, March 2004.

32 What Do People Bring Into the Game: Experiments in the Field About Cooperation in the Commons, by Juan-Camilo Cárdenas and Elinor Ostrom, June 2004.

33 Methods for Studying Collective Action in Rural Development, by Ruth Meinzen-Dick, Monica Di Gregorio, and Nancy McCarthy, July 2004.

34 The Relationship between Collective Action and Intensification of Livestock Production: The Case of Northeastern Burkina Faso, by Nancy McCarthy, August 2004.

35 The Transformation of Property Rights in Kenya's Maasailand: Triggers and Motivations by Esther Mwangi, January 2005.

36 Farmers' Rights and Protection of Traditional Agricultural Knowledge, by Stephen B. Brush, January 2005.

37 Between Conservationism, Eco-Populism and Developmentalism: Discourses in Biodiversity Policy in Thailand and Indonesia, by Heidi Wittmer and Regina Birner, January 2005.

38 Collective Action for the Conservation of On-Farm Genetic Diversity in a Center of Crop Diversity: An Assessment of the Role of Traditional Farmers' Networks, by Lone B. Badstue, Mauricio R. Bellon, Julien Berthaud, Alejandro Ramírez, Dagoberto Flores, Xóchitl Juárez, and Fabiola Ramírez, May 2005.

39 Institutional Innovations Towards Gender Equity in Agrobiodiversity Management: Collective Action in Kerala, South India,, by Martina Aruna Padmanabhan, June 2005.

40 The Voracious Appetites of Public versus Private Property: A View of Intellectual Property and Biodiversity from Legal Pluralism, by Melanie G. Wiber, July 2005.

41 Who Knows, Who Cares? Determinants of Enactment, Awareness and Compliance with Community Natural Resource Management Bylaws in Uganda, by Ephraim Nkonya, John Pender, Edward Kato, Samuel Mugarura, and James Muwonge, August 2005.

42 Localizing Demand and Supply of Environmental Services: Interactions with Property Rights, Collective Action and the Welfare of the Poor, by Brent Swallow, Ruth Meinzen-Dick, and Meine von Noordjwik, September 2005. 
43 Initiatives for Rural Development through Collective Action: The Case of Household Participation in Group Activities in the Highlands of Central Kenya, By Gatarwa Kariuki and Frank Place, September 2005.

44 Are There Customary Rights to Plants? An Inquiry among the Baganda (Uganda), with Special Attention to Gender, by Patricia L. Howard and Gorettie Nabanoga, October 2005.

45 On Protecting Farmers' New Varieties: New Approaches to Rights on Collective Innovations in Plant Genetic Resources by Rene Salazar, Niels P. Louwaars, and Bert Visser, January 2006.

46 Subdividing the Commons: The Politics of Property Rights Transformation in Kenya's Maasailand, by Esther Mwangi, January 2006.

47 Biting the Bullet: How to Secure Access to Drylands Resources for Multiple Users, by Esther Mwangi and Stephan Dohrn, January 2006.

48 Property Rights and the Management of Animal Genetic Resources, by Simon Anderson and Roberta Centonze, February 2006.

49 From the Conservation of Genetic Diversity to the Promotion of Quality Foodstuff: Can the French Model of Appellation d'Origine Contrôlée' be Exported? by Valérie Boisvert, April 006.

50 Facilitating Collective Action and Enhancing Local Knowledge: A Herbal Medicine Case Study in Talaandig Communities, Philippines, by Herlina Hartanto and Cecil Valmores, April 2006.

51 Water, Women, and Local Social Organization in the Western Kenya Highlands, by Elizabeth Were, Brent Swallow, and Jessica Roy, July 2006.

52 The Many Meanings of Collective Action: Lessons on Enhancing Gender Inclusion and Equity in Watershed Management, by Laura German, Hailemichael Taye, Sarah Charamila, Tesema Tolera, and Joseph Tanui, July 2006.

53 Decentralization and Environmental Conservation: Gender Effects from Participation in Joint Forest Management, by Arun Agrawal, Gautam Yadama, Raul Andrade, and Ajoy Bhattacharya, July 2006.

54 Improving the Effectiveness of Collective Action: Sharing Experiences from Community Forestry in Nepal, by Krishna P. Achyara and Popular Gentle, July 2006.

55 Groups, Networks, and Social Capital in the Philippine Communities, by Marie Godquin and Agnes R. Quisumbing, October 2006.

56 Collective Action in Plant Genetic Resources Management: Gendered Rules of Reputation, Trust and Reciprocity in Kerala, India, by Martina Aruna Padmanabhan, October 2006.

57 Gender and Local Floodplain Management Institutions--A case study from Bangladesh, by Parvin Sultana and Paul Thompson, October 2006.

58 Gender Differences in Mobilization for Collective Action: Case Studies of Villages in Northern Nigeria, by Saratu Abdulwahid, October 2006.

59 Gender, Social Capital, and Information Exchange in Rural Uganda, by Enid Katungi, Svetlana Edmeades, and Melinda Smale, October 2006.

60 Rural Institutions and Producer Organizations in Imperfect Markets: Experiences from Producer Marketing Groups in Semi-Arid Eastern Kenya, by Bekele Shiferaw, Gideon Obare and Geoffrey Muricho, November 2006.

61 Women's Collective Action and Sustainable Water Management: Case of SEWA's Water Campaign in Gujarat, India, by Smita Mishra Panda, October 2006.

62 Could Payments for Environmental Services Improve Rangeland Management inCentral Asia, West Asia and North Africa? by Celine Dutilly-Diane, Nancy McCarthy, Francis Turkelboom, Adriana Bruggeman, James Tiedemann, Kenneth Street and Gianluca Serra, January 2007.

63 Empowerment through Technology: Gender Dimensions of Social Capital Build-Up in Maharashtra, India, by Ravula Padmaja and Cynthia Bantilan, February 2007. 
64 Gender and Collective Action: A Conceptual Framework for Analysis, by Lauren Pandolfelli, Ruth Meinzen-Dick, and Stephan Dohrn, May 2007.

65 Gender, Wealth, and Participation in Community Groups in Meru Central District, Kenya, by Kristin E. Davis and Martha Negash, May 2007.

66 Beyond Group Ranch Subdivision: Collective Action for Livestock Mobility, Ecological Viability, and Livelihoods, by Shauna BurnSilver and Esther Mwangi, June 2007.

67 Farmer Organization, Collective Action and Market Access in Meso-America, by Jon Hellin, Mark Lundy, and Madelon Meijer, October 2007.

68 Collective Action for Innovation and Small Farmer Market Access: The Papa Andina Experience, by André Devaux, Claudio Velasco, Gastón López, Thomas Bernet, Miguel Ordinola, Hernán Pico, Graham Thiele, and Douglas Horton, October 2007.

69 Collective Action and Marketing of Underutilized Plant Species: The Case of Minor Millets in Kolli Hills, Tamil Nadu, India, by Guillaume P. Gruère, Latha Nagarajan, and E.D.I. Oliver King, M.S. Swaminathan Research Foundation, October 2007.

70 The Role of Public-Private Partnerships and Collective Action in Ensuring Smallholder Participation in High Value Fruit and Vegetable Supply Chains, by Clare Narrod, Devesh Roy, Julius Okello, Belem Avendaño, and Karl Rich, October 2007.

71 Collective Action for Small-Scale Producers of Agricultural Biodiversity Products, by Froukje Kruijssen, Menno Keizer, and Alessandra Giuliani, October, 2007.

72 Farmer Groups Enterprises and the Marketing of Staple Food Commodities in Africa, by Jonathan Coulter, October 2007.

73 Linking Collective Action to Non-Timber Forest Product Market for Improved Local Livelihoods: Challenges and Opportunities, by Heru Komarudin, Yuliana L. Siagian, and Ngakan Putu Oka, December, 2007.

74 Collective Action Initiatives to Improve Marketing Performance: Lessons from Farmer Groups in Tanzania, by James Barham and Clarence Chitemi, March 2008.

75 Sustaining Linkages to High Value Markets through Collective Action In Uganda: The Case of the Nyabyumba Potato Farmers, by Elly Kaganzi, Shaun Ferris, James Barham, Annet Abenakyo, Pascal Sanginga, and Jemimah Njuki, March 2008.

76 Fluctuating Fortunes of a Collective Enterprise: The Case of the Agroforestry Tree Seeds Association of Lantapan (ATSAL) in the Philippines, by Delia Catacutan, Manuel Bertomeu, Lyndon Arbes, Caroline Duque, and Novie Butra, April 2008. 